\title{
CONSUMERS' RESEARCH ON COSMETIC BRANDS PREFERENCE AND PURCHASING BEHAVIOR: THAI BRANDS AND CHINESE DOMESTIC BRANDS
}

\author{
Cai Yun Pu ${ }^{1}$ \\ Intemational College \\ Rajamangala University of Technology Krungthep Thailand \\ 27719371@qq.com ${ }^{1}$ \\ Nico Irawan ${ }^{2}$ \\ Intemational College \\ Rajamangala University of Technology Krungthep Thailand \\ nico.i@mail.rmutk.ac.th
}

\begin{abstract}
The research theme is put forward under the realistic background of the development of Thai cosmetics in the Chinese market. Intends to start from cosmetics, with some college students and working youth groups as samples to study the evolution of Thai cosmetics in the Chinese market. Based on reviewing the research results of related topics at home and abroad, this paper draws on the classic consumer ethnocentrism and Chinese goods purchasing behavior relationship model, collects data through questionnaires, and uses SPSS data analysis software to trust the recovered data, validity test, and regression analysis to test each hypothesis. The results confirmed the consumer's relationship between the category of cosmetics, Chinese goods awareness and brand preference, brand identity perception and purchase, and their variables in the context of Chinese and Thai brands. And help Thai cosmetics manufacturers to gain a deeper understanding of the Chinese market and consumers, and formulate effective strategies to enter the entering China.
\end{abstract}

Keywords: Consumer Chinese goods awareness, Brand preference, Brand identity cognition, Brand purchase behavior. 


\section{INTRODUCTION}

Today's market has entered an era dominated by brand competition. After decades of reform and opening-up and China's accession to the WTO, the overall size of the market has expanded dozens of times, and more and more foreign brands have entered the domestic market. It can be speculated that there is still a huge development potential in China's cosmetics market (Wang, 2005), and the transaction scale will grow steadily in the next few years. With the gradual deepening of political and economic exchanges between China and Thailand, Thai cosmetics brands have gradually entered the Chinese market (Zhuang, 2006) and have good development prospects.

"Chinese goods awareness" is generally regarded as the localization of the concept of "consumer ethnocentrism" in China. "Consumer ethnocentrism" was first proposed by Sharma (1987), which has been widely studied in western countries. The impact of this concept on a country's national consumption behavior generally regarded as the research focus. The earlier classic research model is also a model of consumer ethnocentric tendencies proposed by Sharma (1987), which focuses on the trend of consumer ethnocentrism to Chinese consumer domestic or foreign goods and joins demographics factors (age, gender, education, income), product necessity cognition, overseas economic turmoil, cognitive three adjustment variables. Domestic research on the concept of local goods is earlier and more systems such as Wang et al. (2007) from the intrinsic relationship between consumer ethnocentrism and domestic product consumption behavior to the ethnocentric behavior of retail store selection in recent years. The research on the significance of its marketing strategy has become more and more detailed and more practical. Later, scholars represented by Zhuang (2006) and others gradually tried to conduct empirical research on products and brands on domestic product awareness, brand characteristics, and consumer local brand preferences.

This article intends to target the broad concept of "foreign brand" and "foreign market" to the development of Thai cosmetics in the Chinese market and consumer attitudes under the realistic background of the strong development of Thai cosmetics in the Chinese market, Conduct behavior and other aspects to do a research in order to expect to draw valuable conclusions. In terms of specific empirical research methods, this article did not make a major breakthrough, mainly on the basis of previous research methods, according to the specific research topics of this article, slightly modified to ensure the credibility and authority of the method. This research is mainly to clarify the problems between domestic product perception, 
brand characteristics, consumer preferences and purchasing behavior. And the following are the research questions: a) When Chinese consumers are confronted with Thai cosmetics and domestic cosmetics, what is the impact of their brand preference on their purchasing behavior? b) When Chinese consumers face Thai cosmetics and domestic cosmetics, what is the impact of their local product awareness on brand preference and purchasing behavior? c) When Chinese consumers face Thai cosmetics and domestic cosmetics, they have different perceptions of Thai brands and local brands, then what is the impact of consumer's brand identity cognition on their brand behavior and purchasing choice? d) Whether consumers have a Thai cosmetics brand buying experience, what is the relationship between their brand identity perception and brand preference?

At present, China's cosmetics market is experiencing a new turning point. And Thailand, with its natural, healthy, and environmentally friendly characteristics, the Thai brand has gradually been accepted by Chinese consumers (Johri, 1998). Therefore, we have reason to predict that the potential for Thai cosmetic brands will increase progressively.

\section{REVIEW OF LITERATURE}

This article focuses on the research of Chinese consumers' preference for Chinese cosmetic brands and Thai cosmetic brands. Zhao Zhanbo and others(2009) conducted a study on Chinese consumers' Chinese and foreign brand preferences and their key influencing factors, and concluded that consumers' age, family, income and education level are the main influencing variables. Some scholars have confirmed that consumers who have had direct purchase experience are more affected by their own buying behaviors. In the absence of direct purchasing experience, consumers judgments on behavior are more based on themselves indirect experience (such as word-of-mouth publicity, advertising, etc.) (Wang Peng, 2014). Wang Rong and Li Hui (2013) draws a sense of Chinese goods has an obvious intention for consumers to buy foreign brand products negative influence.

\section{RESEARCH METHODS}

This study used statistical analysis software SPSS 17.0 for data statistics and analysis (Verma, 2012). This study used one of the most commonly used regression analysis methods, linear regression, that is, to study whether there is a direct relationship between the dependent variable and one or more independent variables. 


\section{Model establishment}

This paper mainly refers to the research mode of several experts and makes some modifications (Zhuang, 2006). Get the model shown in Figure 1 below.

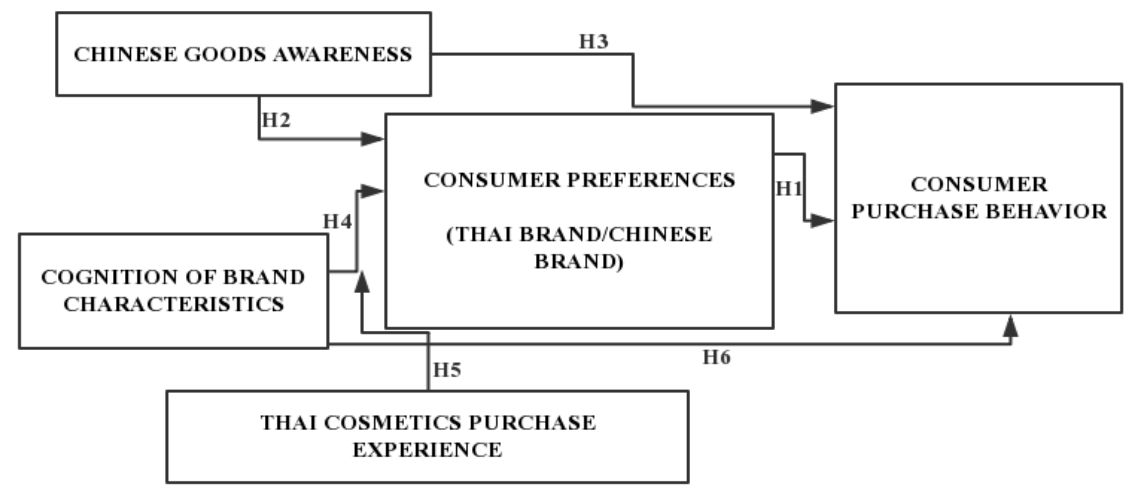

Figure 1: Research model in this paper

Because of the cosmetics as the research object, we want to find out the influence of Chinese consumers' preference (Wang, 2016) on their purchasing choices in the context of the Thai cosmetic brand and the domestic cosmetics brand, and whether consumers prefer to buy such a brand. Then made the following assumptions.

H1a: All other things being equal, the more Chinese consumers prefer domestic cosmetics brands, the more they tend to buy local cosmetics brands.

H1b: All other things being equal, the more Chinese consumers prefer Thai cosmetics brands, the more they tend to buy Thai cosmetics brands.

This paper wants to clarify whether brand preference and purchasing behavior are affected by the awareness of domestic products and how they are affected (He, 2012). Therefore, the following assumptions are made.

$\mathrm{H} 2$ : All other things being equal, the stronger the Chinese consumers' awareness of domestic cosmetic products, the more they prefer the local cosmetics brand over the Thai cosmetic brands. H3: All other things being equal, the stronger the Chinese consumer's awareness of domestic products, the more inclined they are to buy local cosmetics brands instead of Thai cosmetics brands.

To understand whether brand preferences and purchasing behavior are affected by domestic product awareness, make the following assumptions.

H4a: All other things being equal, the higher the Chinese consumers' perception of the characteristics of domestic cosmetics brands, the more they prefer local cosmetics brands. 
H4b: All other things being equal, the higher the Chinese consumers' perception of the characteristics of Thai cosmetics brands, the more they prefer the Thai cosmetics brand.

H5a: All other things being equal, the Chinese consumers' Thai brand buying experience regulates the relationship between consumer brand identity perception and brand preference.

H5b: All other things being equal, the more consumers who have not had the purchase experience of the Thai cosmetic brand, the stronger the influence of consumers' perception of Chinese domestic cosmetics brand on consumers' preference for Chinese local cosmetics brands.

H6a: All other things being equal, the higher the consumer's perception of the characteristics of Chinese domestic cosmetics brands, the more they tend to buy Chinese local cosmetics brands.

H6b: All other things being equal, the higher the consumer's perception of the characteristics of Thai cosmetics brands, the more they tend to buy Thai cosmetics brands.

\section{Research brand selection}

The choice of brand is mainly based on the following two aspects. On the one hand, both the Thai cosmetic brands and the Chinese domestic cosmetic brands are mostly based on the top brands in the local market (Zhuang et al. 2006). On the other hand, we have preferentially selected several Thai cosmetics brands with the highest sales volume, and then choose the same product category as the Thai cosmetics brands in the selection of domestic cosmetics brands. Based on the above considerations, the product categories and brands included in the study are as follows in table 1.

Table 1 Research on Brand and Category

\begin{tabular}{l|l|l|l|l|l}
\hline $\begin{array}{l}\text { Product } \\
\text { category } \\
\text { Brands }\end{array}$ & $\begin{array}{l}\text { Facial } \\
\text { Cleanser }\end{array}$ & Mask & Skin Cream & Skin Lotion & Make-up \\
\hline \multirow{2}{*}{ Thai Brands } & $\begin{array}{l}\text { BEAUTY } \\
\text { BUFFET }\end{array}$ & $\begin{array}{l}\text { ELE } \\
\text { VOODOO }\end{array}$ & $\begin{array}{l}\text { SNAIL } \\
\text { WHITE }\end{array}$ & $\begin{array}{l}\text { ORIENTAL } \\
\text { PRINCESS } \\
\text { SNAIL } \\
\text { WHITE }\end{array}$ & $\begin{array}{l}\text { MISTINE } \\
\text { BSC }\end{array}$ \\
\hline Chinese Brands & $\begin{array}{l}\text { PECHOIN } \\
\text { INOHERB }\end{array}$ & $\begin{array}{l}\text { KANS } \\
\text { UNIFON }\end{array}$ & $\begin{array}{l}\text { MARUBI } \\
\text { HERBORIST }\end{array}$ & $\begin{array}{l}\text { HERBORIST } \\
\text { CHANDO }\end{array}$ & $\begin{array}{l}\text { FLAMINGO } \\
\text { CARSLAN }\end{array}$ \\
\hline
\end{tabular}

\section{RESULTS AND DISCUSSION}

\section{Sample background analysis}

A total of 250 questionnaires were distributed in this study, and 220 surveys were collected, with a recovery rate of $88 \%$. Because this study is aimed at young and middle-aged women (college students and working young women), 3 of them were excluded from the invalid 
questionnaires (Ponbamrungwong, 2009). The final valid polls were 217. The elemental composition is shown in Table 2 below. As can be seen from the table, the age of the survey participants is $92.6 \%$ from 16 to 30 . Between the ages, only $7.4 \%$ are from 31 to 40 years old, which helps the questionnaire to be more representative.

Table 2 Sample background structure

\begin{tabular}{l|l|l|l}
\hline \multirow{4}{*}{ QUESTION } & OPTION & FREQUENCY & PERCENTAGE \\
\hline \multirow{4}{*}{ AGE } & MALE & 0 & 0 \\
\cline { 2 - 4 } & FEMALE & 217 & 100 \\
\hline \multirow{4}{*}{ Buying Cosmetics Experience } & $16-25$ years old & 114 & 52.5 \\
\cline { 2 - 4 } & 26-30 years old & 87 & 40.1 \\
\cline { 2 - 4 } & 31-40 years old & 16 & 7.4 \\
\cline { 2 - 4 } & NO years old or older & 0 & 0 \\
\hline \multirow{2}{*}{ TOTAL } & NO & 217 & 100 \\
\hline
\end{tabular}

Five factors for order cosmetics. The results are shown in Table 4 below. As can be seen, most consumers do not care much about the origin of the brand when purchasing cosmetics.

The item includes five factors: brand origin, brand awareness, brand quality, and brand price (Chan, 2009). Ask investigators to sort and get the table 3.

Table 3 Cosmetics purchase considerations

\begin{tabular}{l|l|l|l|l|l|l|l|l|l|l}
\hline & \multicolumn{2}{|l|}{ First place } & \multicolumn{2}{l|}{ Second place } & \multicolumn{2}{l|}{ Third place } & \multicolumn{2}{l|}{ Fourth place } & \multicolumn{2}{l}{ Fiffh place } \\
\hline & $\mathrm{F}$ & $\mathrm{P}(\%)$ & $\mathrm{F}$ & $\mathrm{P}(\%)$ & $\mathrm{F}$ & $\mathrm{P}(\%)$ & $\mathrm{F}$ & $\mathrm{P}(\%)$ & $\mathrm{F}$ & $\mathrm{P}(\%)$ \\
\hline Country of origin & 3 & 1.38 & 3 & 1.45 & 9 & 4.41 & 31 & 15.9 & 148 & 77.08 \\
\hline Popularity & 11 & 5.07 & 22 & 10.63 & 13 & 6.37 & 126 & 64.62 & 29 & 15.1 \\
\hline Quality & 132 & 60.38 & 67 & 32.37 & 6 & 2.94 & 5 & 2.56 & 0 & 0 \\
\hline Price & 1 & 0.46 & 48 & 23.19 & 128 & 62.75 & 19 & 9.74 & 9 & 4.69 \\
\hline Value for money & 70 & 32.26 & 67 & 32.37 & 48 & 23.53 & 14 & 7.18 & 6 & 3.13 \\
\hline Total & 217 & 100 & 217 & 100 & 217 & 100 & 217 & 100 & 217 & 100 \\
\hline
\end{tabular}

Legend:

F: Frequency

P: Percentage

As can be seen, most consumers do not care much about the origin of the brand when purchasing cosmetics. 


\section{Reliability and Validity Test}

\section{Reliability Test Analysis}

The $\alpha$ coefficient created by L. J. Cronbach is a commonly used method for testing reliability in the attitude scale method. The value of the alpha coefficient judges the magnitude of the reliability. This paper also quotes the scale, and made some changes to the subject of this study, and obtained seven items of China. The goods awareness scale, the measurement results are shown in Table 4 below, the $\alpha$ value is 0.785 , the reliability is excellent, and the validity test can be continued.

Table 4 Reliability Analysis of Chinese Goods Awareness Scale

\begin{tabular}{l|l|l}
\hline $\begin{array}{l}\text { Cronbach's } \\
\text { Alpha }\end{array}$ & $\begin{array}{l}\text { Cronbach's Alpha Based on standardized } \\
\text { items }\end{array}$ & Number of items \\
\hline .785 & .782 & 7 \\
\hline
\end{tabular}

\section{Validity test analysis}

At present, SPSS provides a standard method for judging whether the original variable is suitable for statistical analysis of factor analysis. In general, a KMO (Kaiser-Meyer-Olkin) measure higher than 0.5 means that factor analysis can be performed, while above 0.7 is more effective. If the KMO measure is more significant than 0.8 , the validity is very high. Table 5 below shows, it can be considered that the correlation coefficient matrix is significantly different from the unit matrix, and it is also suitable for factor analysis, that is, the validity is highly reliable.

Table 5 Validity Analysis of China Goods Awareness Scale

\begin{tabular}{l|c}
\hline Measurement item & $\begin{array}{l}\text { Fact } \\
\text { or } \\
\text { load }\end{array}$ \\
\hline $\begin{array}{l}\text { G1 Chinese should give priority to buying Chinese domestic brands to protect } \\
\text { the development of national industries. }\end{array}$ & .611 \\
\hline G2 China's national brand is gradually growing and proud. & .654 \\
\hline $\begin{array}{l}\text { G3 Foreign brands pose a concern about China's related industries and } \\
\text { markets. }\end{array}$ & .680 \\
\hline $\begin{array}{l}\text { G4 The expansion of foreign brands such as L'Oreal Paris, Estee Lauder, and } \\
\text { Lancome in China is unsettling. }\end{array}$ & .761 \\
\hline $\begin{array}{l}\text { G5 China's national brands should not be allowed to be acquired by foreigners } \\
\text { in any way. (D) }\end{array}$ & .492 \\
\hline G6 Chinese should use Chinese own "cosmetics." & .762 \\
\hline $\begin{array}{l}\text { G7 Consumer acceptance of Chinese brands is directly related to the } \\
\text { sustainable development of national enterprises and the Chinese economy. (D) }\end{array}$ & .736 \\
\hline
\end{tabular}


KMO and Bartlett's inspection

\begin{tabular}{|l|l|l}
\multicolumn{2}{|l|}{$\begin{array}{l}\text { Kaiser-Meyer-Olkin Measure of Sampling } \\
\text { Sufficiency }\end{array}$} & .762 \\
\hline \multirow{3}{*}{$\begin{array}{l}\text { Bartlett's } \\
\text { spherical test }\end{array}$} & Approximate Chi-Square & $\begin{array}{l}573 . \\
897\end{array}$ \\
\cline { 2 - 3 } & df & 21 \\
\cline { 2 - 3 } & Sig. & .000 \\
\hline
\end{tabular}

\section{Descriptive statistics}

Table 6 shows the results of the statistical scales for all valid samples. As can be seen from the table, the perspective of brand preference and purchase quantity, the average score of Chinese brands is higher than that of Thai brands. It may be caused by factors such as purchasing channels and brand awareness in the domestic market. In the three characteristics of brand awareness, brand quality, and cost performance, China brand is superior to the Thailand brand; the difference is not big and not very significant. Still, there is a big difference in brand awareness.

Table 6 Total descriptive statistics

\begin{tabular}{l|l|l|l|l|l|l}
\hline \multirow{2}{*}{} & $\mathrm{N}$ & $\begin{array}{l}\text { Minimum } \\
\text { value }\end{array}$ & $\begin{array}{l}\text { Maximum } \\
\text { value }\end{array}$ & $\begin{array}{l}\text { Average } \\
\text { value }\end{array}$ & $\begin{array}{l}\text { Standard } \\
\text { deviation }\end{array}$ \\
\hline Chinese goods awareness & 217 & 1 & 6.29 & 4.51 & 0.78 \\
\hline \multirow{2}{*}{$\begin{array}{l}\text { Brand } \\
\text { preference }\end{array}$} & $\begin{array}{l}\text { Chinese } \\
\text { Brand }\end{array}$ & 217 & 1 & 6 & 4.51 & 0.94 \\
\cline { 2 - 7 } & Thai Brand & 217 & 1 & 6.2 & 4.17 & 1.01 \\
\hline \multirow{2}{*}{$\begin{array}{l}\text { Brand } \\
\text { awareness }\end{array}$} & $\begin{array}{l}\text { Chinese } \\
\text { Brand }\end{array}$ & 217 & 1 & 7 & 6.17 & 1.25 \\
\cline { 2 - 7 } Brand quality & Thai Brand & 217 & 1 & 6.2 & 4.19 & 1.14 \\
\hline \multirow{2}{*}{ Brand price } & Brand & 217 & 1 & 6.8 & 4.73 & 0.84 \\
\cline { 2 - 7 } & Thai Brand & 217 & 1 & 6.4 & 4.42 & 1.01 \\
\hline & $\begin{array}{l}\text { Chinese } \\
\text { Brand }\end{array}$ & 217 & 1 & 6.8 & 4.66 & 0.83 \\
\hline \multirow{2}{*}{$\begin{array}{l}\text { Purchase } \\
\text { quantity }\end{array}$} & $\begin{array}{l}\text { Chainese } \\
\text { Brand }\end{array}$ & 217 & 1 & 6.4 & 4.41 & 0.96 \\
\cline { 2 - 7 } & Thai Brand & 217 & 0 & 5 & 1.66 & 0.87 \\
\hline
\end{tabular}

\section{Research hypothesis test}

\section{Test H1}

As shown in Table 7 below, there is a moderate negative linear correlation between the two variables, which can be entered into the next step of regression analysis. 
Table 7 The relationship between consumer brand preference and purchasing propensity

\begin{tabular}{l|l|l|l|l}
\hline \multicolumn{2}{l|}{} & LIKE & N1 & N2 \\
\hline \multirow{4}{*}{ LIKE } & Pearson correlation & 1 & $.351^{* *}$ & $-.351^{* *}$ \\
& Significant (bilateral) & & .000 & .000 \\
& $\mathrm{~N}$ & 217 & 217 & 217 \\
\hline \multirow{3}{*}{$\mathrm{N} 1$} & Pearson correlation & $.351^{* *}$ & 1 & $-1.000^{* *}$ \\
& Significant (bilateral) & .000 & & \\
& $\mathrm{~N}$ & 217 & 217 & 217 \\
$\mathrm{~N} 2$ & Pearson correlation & $-.351^{* *}$ & $-1.000^{* *}$ & 1 \\
& Significant (bilateral) & .000 & .000 & \\
& $\mathrm{~N}$ & 217 & 217 & 217 \\
\hline
\end{tabular}

Legend:

**. Significant correlation at the level of. 01 (bilateral)

It can be concluded that the more Chinese consumers prefer Chinese cosmetics brands, the more they tend to buy Chinese cosmetics brands, that is, the results support H1a. When other things are the same, the more Chinese consumers prefer the Thai cosmetics brand, the more they tend to buy the Thai cosmetics brand, that is, the result supports H1b.

\section{Test H2, H3}

As shown in table 8, there is a slight positive linear correlation between the two variables.

Table 8 An Analysis of Consumers' Consciousness of Chinese Goods, Brand Preference and Purchasing Tendency of Chinese Brands

\begin{tabular}{l|l|l|l|l}
\hline \multicolumn{2}{l|}{} & CGA & LIKE & N1 \\
\hline \multirow{3}{*}{ CGA } & Pearson correlation & 1 & -.117 & $.203^{* *}$ \\
& Significant (bilateral) & & .086 & .003 \\
& $N$ & 217 & 217 & 217 \\
\hline \multirow{3}{*}{ LIKE } & Pearson correlation & -.117 & 1 & $.351^{* *}$ \\
& Significant (bilateral) & .086 & & .000 \\
& $N$ & 217 & 217 & 217 \\
\hline \multirow{3}{*}{$N 1$} & Pearson correlation & $.203^{* *}$ & $.351^{* *}$ & 1 \\
& Significant (bilateral) & .003 & .000 & \\
& $N$ & 217 & 217 & 217 \\
\hline
\end{tabular}

Legend:

**. Significant correlation at the level of. 01 (bilateral)

It can be concluded that the influence of Chinese consumers' domestic awareness on their local brand preferences is not significant, and the verification results do not support H2. The stronger the Chinese consumers' perception of local products, the more likely they purchase Chinese cosmetics brands instead of Thai cosmetics brands. That is, the result supports H3. 


\section{Test H4, H5}

As shown in Table 9 below, it can be seen that consumer brand preference is moderately positively linearly related to the three characteristic cognitive variables, which can be entered into the next step of regression analysis.

Table 9 Consumer brand identity cognition and brand preference analysis

\begin{tabular}{|c|c|c|c|c|c|}
\hline & & LIKE & KNOW & QUALITY & VALUE \\
\hline \multirow{3}{*}{ LIKE } & Pearson correlation & 1 & $.398 * *$ & $.512 * *$ & $.467 * *$ \\
\hline & Significant & & .000 & .000 & .000 \\
\hline & $\mathrm{N}$ & 217 & 217 & 217 & 217 \\
\hline \multirow{3}{*}{ KNOW } & Pearson correlation & $.398 * *$ & 1 & $.622 * *$ & $.430 * *$ \\
\hline & Significant & .000 & & .000 & .000 \\
\hline & $\mathrm{N}$ & 217 & 217 & 217 & 217 \\
\hline \multirow{3}{*}{ QUALITY } & Pearson correlation & $.512 * *$ & $.622 * *$ & 1 & $.723^{* *}$ \\
\hline & Significant & .000 & .000 & & .000 \\
\hline & $\mathrm{N}$ & 217 & 217 & 217 & 217 \\
\hline \multirow{3}{*}{ VALUE } & Pearson correlation & $.467 * *$ & $.430 * *$ & $.723^{* *}$ & 1 \\
\hline & $\begin{array}{l}\text { Significant } \\
\text { (bilateral) }\end{array}$ & .000 & .000 & .000 & \\
\hline & $\mathrm{N}$ & 217 & 217 & 217 & 217 \\
\hline
\end{tabular}

Legend :

**. Significant correlation at the level of. 01 (bilateral)

It can be concluded that in other cases, the higher the Chinese consumers' perception of the characteristics of Chinese cosmetics brands, the more they prefer Chinese cosmetics brands, and the verification results tend to support H4a, H4b. The more Chinese consumers who have not experienced the purchase of Thai cosmetics brands, the more influence of consumer Chinese cosmetics brand characteristics on consumers' preference for Chinese cosmetics brands, that is, the result supports H5b.

\section{Test H6}

As shown in table 10, it can be seen that consumer brand preference is also moderately negatively linearly related to the three characteristic cognitive variables, and can enter the next step of regression analysis. 
Table 10 Analysis of Consumers' Brand Characteristics Cognition and Brand Purchasing Tendency

\begin{tabular}{l|l|l|l|l|l|l}
\hline \multicolumn{2}{c|}{} & KNOW & QUALITY & VALUE & N1 & N2 \\
\hline \multirow{3}{*}{ KNOW } & Pearson correlation & 1 & $.622^{* *}$ & $.430^{* *}$ & $.226^{* *}$ & $-.226^{* *}$ \\
& Significant (bilateral) & & .000 & .000 & .001 & .001 \\
& $\mathrm{~N}$ & 217 & 217 & 217 & 217 & 217 \\
\hline \multirow{3}{*}{ QUALITY } & Pearson correlation & $.622^{* *}$ & 1 & $.723^{* *}$ & $.258^{* *}$ & $-.258^{* *}$ \\
& Significant (bilateral) & .000 & & .000 & .000 & .000 \\
& $\mathrm{~N}$ & 217 & 217 & 217 & 217 & 217 \\
\hline \multirow{3}{*}{ VALUE } & Pearson correlation & $.430^{* *}$ & $.723^{* *}$ & 1 & $.143^{*}$ & $-.143^{*}$ \\
& Significant (bilateral) & .000 & .000 & & .035 & .035 \\
& $\mathrm{~N}$ & 217 & 217 & 217 & 217 & 217 \\
\hline \multirow{3}{*}{$\mathrm{N} 1$} & Pearson correlation & $.226^{* *}$ & $.258^{* *}$ & $.143^{*}$ & 1 & $-1.000^{* *}$ \\
& Significant (bilateral) & .001 & .000 & .035 & & .000 \\
& $\mathrm{~N}$ & 217 & 217 & 217 & 217 & 217 \\
\hline \multirow{3}{*}{$\mathrm{N} 2$} & Pearson correlation & $-.226^{* *}$ & $-.258^{* *}$ & $-.143^{*}$ & $-1.000^{* *}$ & 1 \\
& Significant (bilateral) & .001 & .000 & .035 & .000 & \\
& $\mathrm{~N}$ & 217 & 217 & 217 & 217 & 217 \\
\hline
\end{tabular}

Legend:

**. Significant correlation at the level of. 01 (bilateral)

*. Significant correlation at the level of. 005 (bilateral)

It can be concluded that the higher perception of the characteristics of Chinese or Thai cosmetics brands, the more inclined to buy the conclusion of Chinese or Thai cosmetics brands; the test results do not support H6b.

\section{CONCLUSION}

In the context of the increasingly frequent economic exchanges between China and Thailand, this paper puts the perspective on the comparison between Thai brands and Chinese brands, and further understands the views of Chinese goods awareness, brand identity perception, brand preference and purchasing behavior among consumers. The favorite and purchase of Chinese consumers in the face of Thai cosmetics brands and Chinese cosmetics brands can also explore the role of Chinese consumers' awareness of Chinese goods and brand identity.

For Chinese or Thai cosmetics suppliers, they can increase users' brand preferences in terms of their brand awareness, quality, image, and cost performance. In this way, consumers will be more inclined to buy Chinese or Thai cosmetics, which is supported by H1. Secondly, consumers will be more willing to buy Chinese cosmetics by increasing their awareness of Chinese 
products, which supports H3. It is verified that the domestic knowledge has a significant impact on consumers' Chinese brand purchases, but the effect on consumer brand preferences is not substantial. For cosmetics suppliers, the higher the consumer's perception of the characteristics of local or Thai cosmetics brands, the more they prefer local or Thai cosmetics brands (H4). It infers that various promotional tools and media can also be used to promote characteristics' perception (Wang, 2015); consumers will be more inclined to buy. For consumers who do not have Thai cosmetics buying experience, they will be more willing to buy Chinese cosmetics, which is supported by H5 (Guo, 2014). Therefore, Thailand's cosmetics suppliers may do free sampling to introduce Thai cosmetic products, then more customers understand Thai cosmetics; the more customers are inclined to purchase.

In the future research process, both the choice of the respondents and the choice of the brand will be considered more comprehensive and try to improve the represent ativeness of the research results. At the same time, we will think deeply about the reasons why the domestic product cognition, brand preference and brand identity cognition are not consistent with the hypothesis. And explore more empirical research.

\section{REFERENCES}

Chan, T., Cui, G., \& Zhou, N. (2009). Competition Between Foreign and Domestic Brands: A Study of Consumer Purchases in China. Journal of Global Marketing, 22(3), 181-197.

Fazio, R. H., Zanna, M. P., \& Cooper, J. (1978). Direct Experience and attitude-behavior Consistency: An Information Processing Analysis. Personality and Social Psychology Bulletin, 4(1), 48-51.

Granzin, K. L., \& Olsen, J. E. (1998). Americans' Choice of Domestic Over Foreign Products: A Replication and Extension. Journal of Business Research, 43(1), 39-54.

Granzin, K. L., \& Painter, J. J. (2018). Motivational Influences on "Buy Domestic" Purchasing: Marketing Management Implications from a Study of Two Nations. Journal of International Marketing, 9(2), 73-96.

Guo, C. H., Wang, J. C., \& Yang, Y. (2014). Improving the competitiveness of local cosmetics. Journal of Daily Chemical Science, 37(4), 41-45.

He, H. P., \& Su, H. Y. (2012). Research on "Local Goods" Consciousness, Brand Characteristics, and Consumers' Local Brand Preference. Journal of Shenzhen University (Humanities and Social Sciences), 29(6), 100-105.

Howard, J. A., \& Sheth, J. N. (1967). A Theory of Buyer Behavior. In B. M. Enis \& K. K. Cox (Eds.), Marketing Classics (105-123). Cambridge: The University Press. 
Huang, Y., Phau, I., Lin, C., Chung, H., \& Lin, K. H. (2008). Allocentrism and consumer ethnocentrism: the effects of social identity on purchase intention. Social Behavior and Personality: an international journal, 36(8), 1097-1110.

Jerónimo, R., Ramos, T., \& Ferreira, M. B. (2018). Trait transference from brands to individuals: The impact of brand-behavior congruency. Journal of Business Research, 88, 54-65.

Johri, L. M., \& Sahasakmontri, K. (1998). Green marketing of cosmetics and toiletries in Thailand. Journal of Consumer Marketing, 15(3), 265-281.

Klein, J. G., Ettenson, R., \& Morris, M. D. (1998). The animosity model of foreign product purchase: An empirical test in the People's Republic of China. Journal of Marketing, 62(1), 89-100.

Kumar, A., Kim, Y., \& Pelton, L. (2009). Indian consumers' purchase behavior toward the US versus domestic brands. International Journal of Retail \& Distribution Management, 37(6), 510-526.

Lai, G. Y. (2010). The typical example of a statistical analysis of the SPSS17 Chinese version. Beijing: Publishing House of Electronics Industry.

Lane Keller, K., \& Moorthi, Y. L. R. (2003). Branding in developing markets. Business Horizons, 46(3), 49-59.

$\mathrm{Li}, \mathrm{P}$. (2013). The influence of the confusion of origin of Chinese and overseas brands on consumers' purchasing intention: the adjustment effect of involvement degree. Corporate Herald, (13), 88-89.

Liu, J., Zhang, W., \& Xiao, Y. (2016). Insight into consumer purchasing decision: domestic product bias or domestic product awareness-an empirical analysis based on total factor questionnaire. Brand Research, (3), 77-84.

Nguyen, A. N. (2012). Consumer behavior toward foreign versus domestic branded cosmetics: A case study in Shenzhen, China. Doctoral Dissertation, University of Phoenix, Phoenix.

Ponbamrungwong, A., \& Chandsawang, S. (2009). The impact of brand on Thai female consumers in the purchase decision of foreign cosmetic products. Retrieved May 30, 2020, from http://www.diva-portal.org/smash/get/diva2:236236/FULLTEXT01.pdf

Qiu, H. Z. (2015). Quantitative research and statistical analysis. Chongqing: Chongqing University Press.

Rheem, H. (1996). International Investing: Who Profits in China. Harvard Business Review, 74(1), 10-11.

Roberts, D. All's Fair in the Brand Wars. Business Week, 29(11), 31. 
Scholz, M., Dorner, V., Landherr, A., \& Probst, F. (2013). The Effects of User- and MarketerGenerated Content on Purchase Decision Processes. Paper presented at the 34th international conference on information systems.

Scholz, M., Schnurbus, J., Haupt, H., Dorner, V., Landherr, A., Probst, F. (2018). Dynamic effects of user- and marketer-generated content on consumer purchase behavior: Modeling the hierarchical structure of social media websites. Decision Support Systems, $113,43-55$.

Shimp, T. A., \& Sharma, S. (1987). Consumer Ethnocentrism: Construction and Validation of the CETSCALE. Journal of Marketing Research, 24(3), 280-289.

Sun, L., \& Zheng, Y. (2009). Review and evaluation of the western country of origin effect theory research. Finance and Trade Economics, (5), 79-84.

Verma, J. P. (2012). Data Analysis in Management with SPSS Software. New Delhi: Springer.

Wang, H. Z. (2005). Research on Chinese Consumer Generation and Its Ethnocentrism Outline. Journal of Management Sciences, 8(6), 88-96.

Wang, H., \& Chen, Z. (2007). The ethnocentric behavior of retail store selection and its marketing strategy. Business Economics and Management, (12), 21-25.

Wang, M. (2015). Analysis of the influence of advertising demand and price factors on the brand attitude of cosmetics consumers under the effect of brand source country is based on the empirical study of female consumers in Shanghai. Master Thesis, East China Normal University, Shanghai.

Wang, P., \& Huang, Q. (2015). The influence of brand origin confusion on brand identity cognition and preference. Journal of Xi'an University of Finance and Economics, 28(4), 79-86.

Wang, R., \& Li, H. (2013). The Influence Mechanism of Consumers' Domestic Product Awareness on the Purchase Intention of Foreign Brand Products-On the Regulating Effect of Consumer Brand Emotions. Economics and Management Research, (3), 102110.

Wang, X. J. (2016). Analysis of the current situation of China's cosmetics market. Market Weekly, (2), 66-67.

Wang, Y. H. \& Fang, S. F. (2007). Research on the influence of the reputation of commercial enterprise agglomeration on consumer purchasing behavior. Management World, (7), 162-163.

Xie, J. F., \& Shen, W. X. (2012). Consumer Ethnocentrism and Local Brand Preference: A Study Based on Empirical Investigation. Jianghuai Forum, (2), 57-62. 
Yuan, S. J., \& Fu, G. Q. (2012). Reasons and analysis of Chinese consumers' cognition differences between domestic and imported products of the same brand. Soft Science, 26(6), 70-77.

Zhuang, G. J., Zhou, N., \& Zhou, L. X. (2006). Chinese goods awareness, brand characteristics, and consumer domestic brand preferences: an empirical test of a cross-industry product. Management World, (7), 85-96. 